\title{
Seismic Activity and Fractal Geometry of Kareh Bas Fault System in Zagros, South of Iran
}

\author{
Mehran Arian', Hamideh Noroozpour ${ }^{2}$ \\ ${ }^{1}$ Department of Geology, Science and Research Branch, Islamic Azad University, Tehran, Iran \\ ${ }^{2}$ Young Researchers and Elites Club, Science and Research Branch, Islamic Azad University, Tehran, Iran \\ Email: mehranarian@yahoo.com
}

Received 11 April 2015; accepted 9 May 2015; published 13 May 2015

Copyright (C) 2015 by authors and Scientific Research Publishing Inc.

This work is licensed under the Creative Commons Attribution International License (CC BY). http://creativecommons.org/licenses/by/4.0/

(c) (i) Open Access

\begin{abstract}
Kareh Bas is one the transverse fault systems in Zagros fold-thrust belt. Kareh Bas Transcurrent Fault System with a total length of $200 \mathrm{Km}$ is situated about $80 \mathrm{Km}$ east of the Borazjan segment (a part of Kazerun fault zone) and $40 \mathrm{Km}$ west of Shiraz. It is a nearly N-S trending right-lateral linked strike-slip fault system, and several anticlinal axes have been displaced by it. Strike separation (109 Km) of Mountain Front Fault/Flexure (MFF) of Zagros is the most important function of Kareh Bas Transcurrent Fault System. According to fractal analysis (Box-counting method) on space image maps $(1: 50,000)$ prepared from Spot data, fault related surface ruptures have non-linear patterns and fault segments have nearly plane form fractal dimensions; specially at north and south terminations. It means that, the north and south terminations of Kareh Bas Transcurrent Fault System are active (earthquake fault segments) and latter case is more active, because it is coinciding on Zagros mountain front faults (MFF).
\end{abstract}

\section{Keywords}

Fractal, Fault, Kareh Bas, Zagros, Transverse, Iran

\section{Introduction}

Kareh Bas is one of the transverse fault systems (Figure 1) in $28^{\circ}$ to $30^{\circ}$ north latitude and $52^{\circ}$ to $58^{\circ} 30^{\prime}$ east longitude. Kareh Bas Transcurrent fault system with a total length of $200 \mathrm{Km}$ is situated at about $40 \mathrm{Km}$ west of Shiraz and continued to south of Deh Ram.

In this research, fractal analysis of Kareh Bas fault system in Zagros, south of Iran has investigated. It has located in the Zagros-East Taurus Hinterland [1]. Dominant structural trends in Zagros province (Figure 2) are 


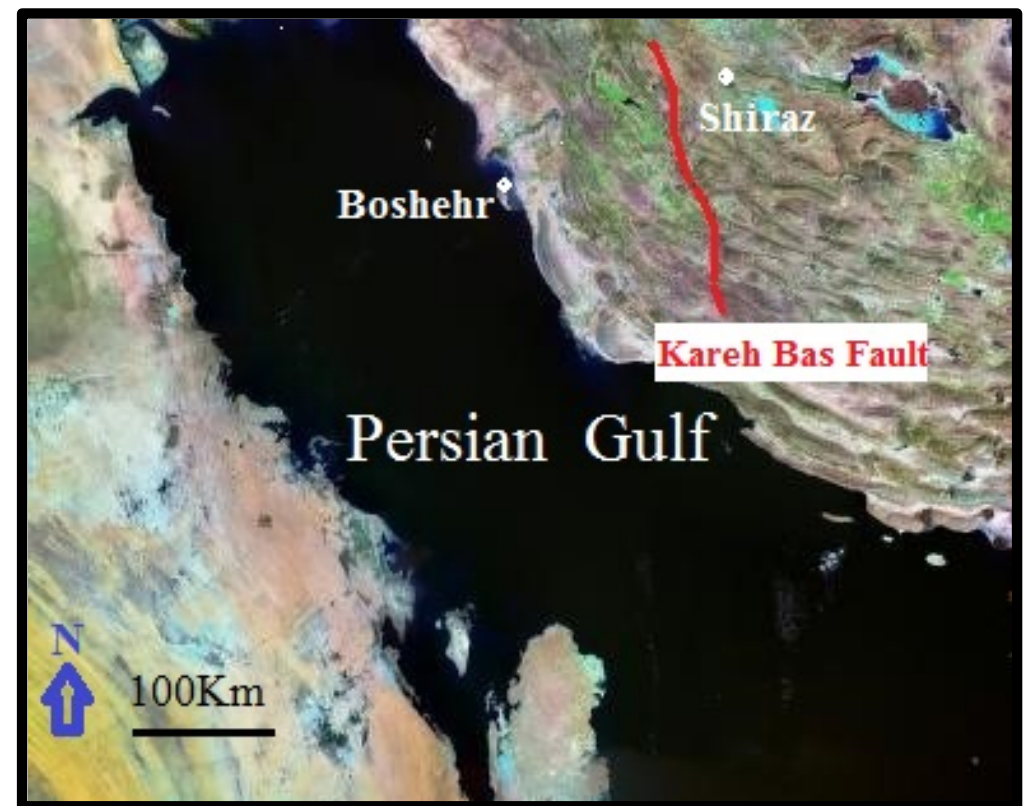

Figure 1. Position of Kareh Bas transverse fault system in Central Zagros on Satellite Image ETM+.

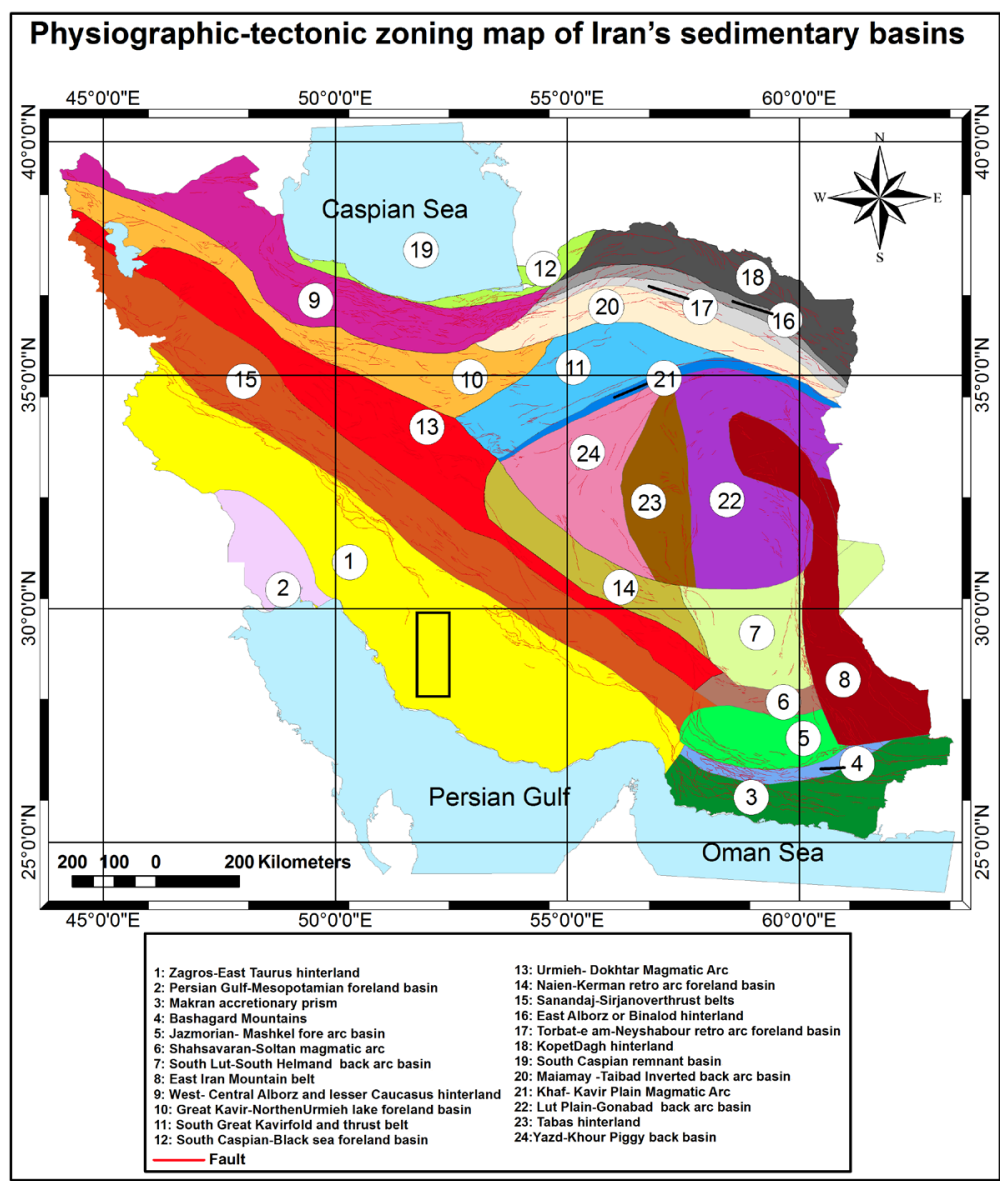

Figure 2. Physiographic-tectonic zoning map of Iran's sedimentary basins Iran modified from [1]. The study area is shown in the black rectangle. 
NW-SE in northwestern part and E-W in southeastern part. From tectonics view, it contains the over thrust and simple fold belts of Zagros that are formed on the northeastern part of Arabian plate's passive margin. Zagros Mountains have continued to East Taurus Mountains in Turkey and have named Zagros-East Taurus hinterland. Zagros-East Taurus hinterland is external platform (fold and thrust belt) of north margin of Arabian Craton. Vergence of folding in this hinterland is toward south and southwest [2] [3].

\section{Materials and Methods}

In this research, the box-counting method has used for fractal analysis Kareh Bas fault system in Zagros and fractal dimension of each segments were calculated by determining of linear regressions in logarithmic diagrams.

Kareh Bas fault system is a nearly N-S trending right-lateral linked strike slip fault system and Dalu, Salamati, Bakak, Dadenjan, Siakh, Khartu-Surmeh [4] and Bahar Anticlines has displaced by it (Figure 3). Kareh BasTranscurrent Fault System consists of six structural segments with relay and anastomosing arrays (Figure 4).

Most of fault segments have smooth continuous mapped traces, because; Jogs had smoothed-out by abrasion and short-cut faults, with increasing displacement. Therefore, there are hard-linkages [5] and shear lens that occurred by development of acognate horses [6]. Also, seven Hormoz salt plugs (Figure 3) have intruded along MTFS [7].

Focal mechanisms of numerous earthquakes are reversed and thrusted [11] such as Naghan and Ardal (Ms = $6.1,1977)$ and or right slip in related to N-S strike slip faults such as Kazeron (SE Boshehr Ms $=6.2,2013$ ) or Kareh Bas (Firozabad-Fars Ms = 6.1, 1994).

Zagros province experiences low to moderate earthquakes with high frequency, short repeat time and 10 - 20 $\mathrm{Km}$ focal depth. Intensity of earthquakes is in middle levels in which there are several ductile rocks (thick evaporates) in sedimentary covers such as Hormuz, Dashtak, and Gachsaran formations. Sometimes in northern margin of this province, focal depths exceed to $70 \mathrm{Km}$ [12] which is an indication of initial stages of thickskinned tectonics.

Also, based on previous work on the salt diapirism [13]-[22] and neotectonics regime in Iran [23], Zagros in south Iran is the most active zone [24]-[36]. Then, Alborz in north Iran [37]-[66] and Central Iran [68]-[76] have been situated in the next orders.

\section{Results and Discussion}

Dominant mechanism of Kareh BasTranscurrent Fault System is Dextral strike slip and the most important function of that, is strike separation of Mountain front fault/flexure (MFF) about 109 Km (Figure 5).

Thus, this large-displacement strike-slip fault system that cut north margin of continental basement of Arabian plate as well as sedimentary cover, should be termed "Transcurrent Fault System" [78]. Also, Isopach and facies maps are indicatives of surface ruptures concerns to post folding of Zagros, because the anticlines had dragged and displaced by Kareh BasTranscurrent Fault System that makes non-gas bearing trend in the Fars area.

Box-counting method has used for fractal analysis [79] and squares with a side of 0.5, 1 and $2 \mathrm{Km}$ have chosen because space image maps have 1:50,000 scale.

Then, fractal dimension of each segments with all related master joints were calculated by determining of linear regressions in logarithmic diagrams. These diagrams show the number of squares in the axis $\mathrm{Y}$ and the inverse length of side squares in the axis X. Fractal dimensions of structural segments have been shown in Table 1 .

Fractal Dimension of segments in Kareh BasTranscurrent Fault System is near to plane-form and therefore, surface development of these, is non-linear.

Great fractal dimension of the sixth segment of Kareh BasTranscurrent Fault System is result of high activity on south termination and development of Kalagh and Daryai fault propagation folds confirms it. Increasing of fractal dimension on structural segments No. 2, 1 to northward and No. 4, 5, 6 (Figure 5) to southward is result of strain concentration at north and south terminations of Kareh BasTranscurrent Fault System. In the other words, increasing of fractal dimension caused to the more non-Linear geometry and frictional behavior. Therefore, there are more seismic events.

\section{Conclusions}

Based on fractal analysis (Box-counting method) on space image maps $(1: 50,000)$ prepared from Spot data, fault 


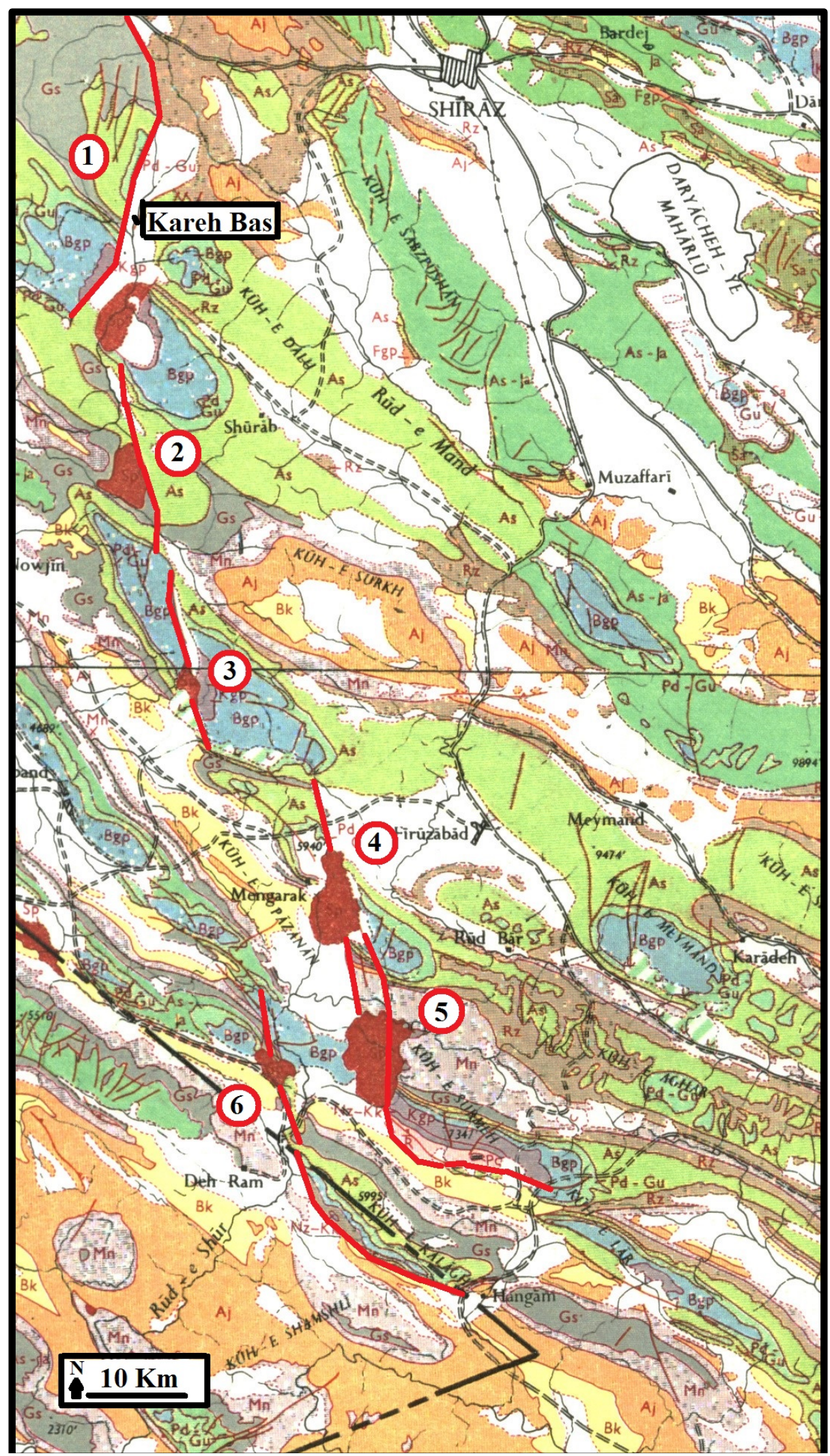

Figure 3. Position of Kareh Bas transverse fault system related to Surrounding Structures on the part of Geological Map of South-West Iran $(1: 1,000,000)$, modified from [8]. 


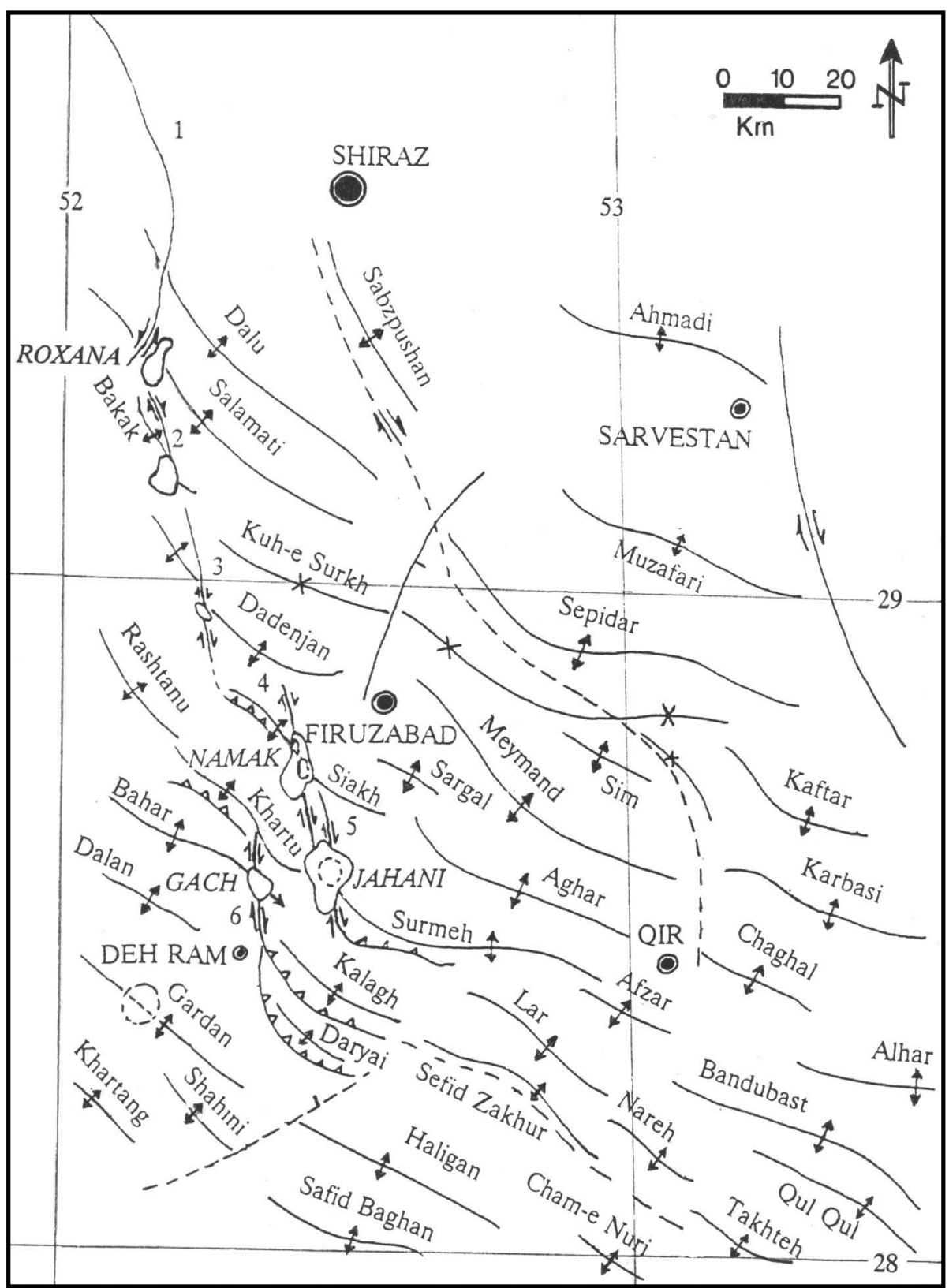

Figure 4. Structural map of Kareh Bas transverse fault system, based on [9] and Shiraz 1:250000 Geological Map [10].

Table 1. Fractal dimensions of structural segments in MTFS.

\begin{tabular}{ccclc|}
\hline Fault Segment & Length $\mathbf{( K m})$ & Fractal Dimension & Geometry & Earthquake Frequency \\
\hline $\mathbf{1}$ & $>60$ & 1.69 & Non-Linear & High \\
$\mathbf{2}$ & 22 & 1.62 & Non-Linear & High \\
$\mathbf{3}$ & 28 & 1.74 & Non-Linear & High \\
$\mathbf{4}$ & 30 & 1.71 & Non-Linear & High \\
$\mathbf{5}$ & $>25$ & 1.75 & Non-Linear & High \\
$\mathbf{6}$ & 34 & 1.76 & Non-Linear & High \\
\hline
\end{tabular}




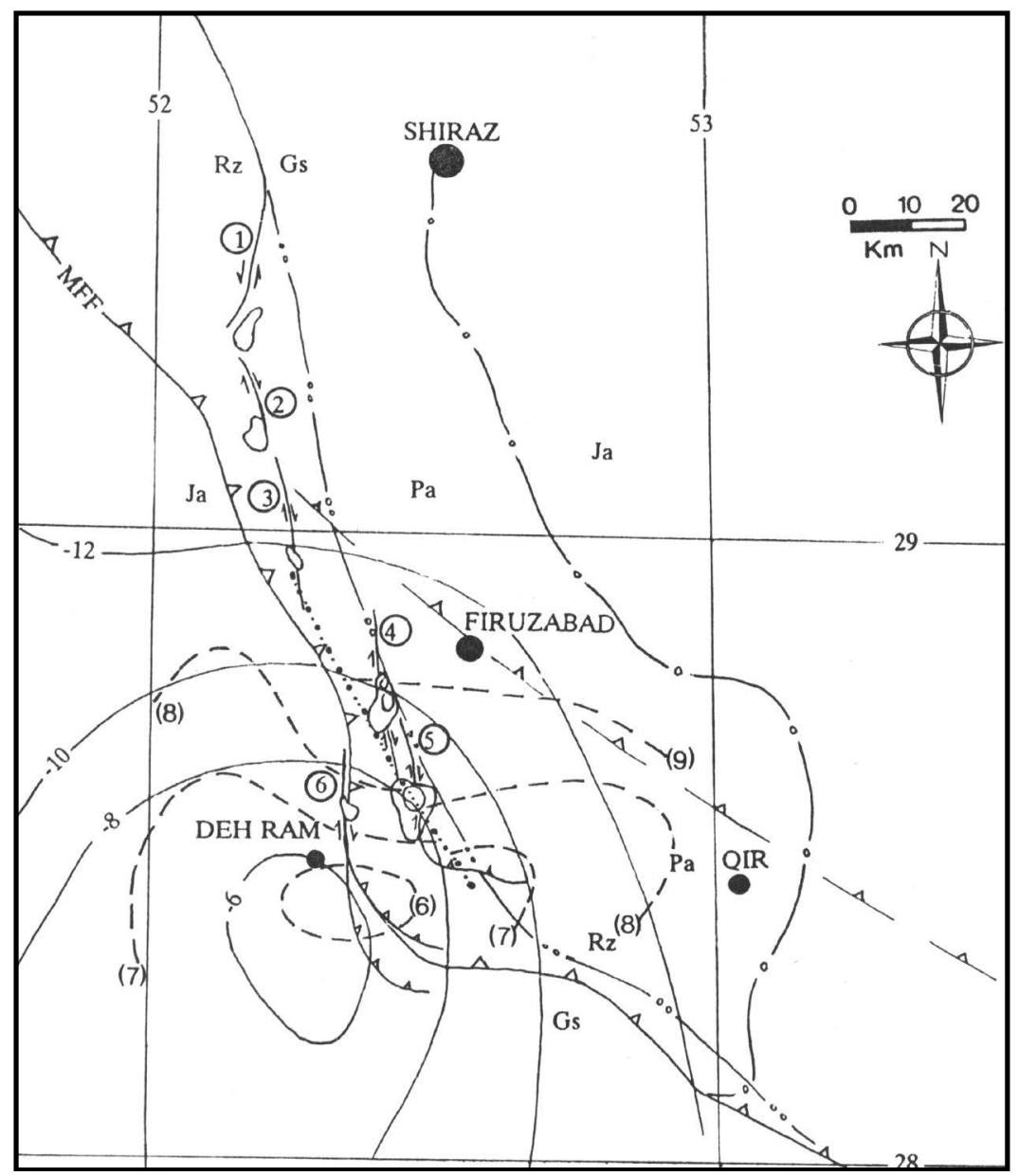

Figure 5. Subsurface Structural map of Kareh Bas transverse fault system and top of basement contour map, based on [9], [10] and [77].

related surface ruptures have non-linear patterns and fault segments have nearly plane form fractal dimensions; specially at north and south terminations. In other words, the north and south terminations of Kareh Bas Trans current Fault System are active, according to its non-linear dimension (1.62 - 1.76). In addition, the south termination is more active (with fractal dimension 1.76), because it is coinciding on Zagros mountain front faults (MFF).

\section{Acknowledgements}

This work has been funded by the Department of geology, Islamic Azad University, Science and Research branch, Tehran, Iran. Also, Special thanks to vice-president for research in Science and Research branch, Tehran.

\section{References}

[1] Arian, M. (2013) Physiographic-Tectonic Zoning of Iran’s Sedimentary Basins. Open Journal of Geology, 3, $169-177$. http://dx.doi.org/10.4236/ojg.2013.33020

[2] Qorashi, M. and Arian, M. (2011) Tectonics of Iran. Geologic Survey of Iran, Tehran, 336 p.

[3] Arian, M. (2011) Basement Tectonics and Geology of Iran. Asar Nafis Press, Qum, 300 p.

[4] Evers, H.J., Fakhari, M. and Verrall, P. (1977) The Geology of the Surmeh and Surrounding Structures, Fars North Area. Report No. 251, National Iranian Oil Company.

[5] Davison, I. (1994) Linked Fault Systems: Extensional, Strike Slip and Contractional. In: Hancock, P.L., Ed., Continental Deformation, Pergamon Press Ltd., Oxford, 121-142. 
[6] Arian, M., Qorashi, M., Pourkermani, M. and Ahmadnia, A. (2006) The Structural Significance Kareh Bas Transcurrent Fault System in the Zagros Fold and Thrust Belt. Journal of Geosciences, Geological Survey of Iran, 15, 126-133.

[7] Arian, M., Pourkermani, M., Qoreshi, M. and Ahmadnia, A. (2002) Salt Diapirism along Mengharak Fault System. Proceedings of the 6th Symposium of Geological Society of Iran Kerman University, Kerman, 2-4 September 2002.

[8] Geological and Exploration Division (1969) Geological Map of South-West Iran, 1:1000000. Geological and Exploration Division, National Iranian Oil Company.

[9] Fakhari, M. (1994) Khormoj 1:250000 Geological Quadrangle Map. Geological Division of Exploration Management, National Iranian Oil Company.

[10] N.I.O.C. (1963) Shiraz 1:250000 Geological Map. The British Petroleum Company Limited. 10. Space Image Maps, Spot Data Acquisition (May-November 1992): Sheets No, 20344, 20351, 20359, 20367, 20374 and 20388. Exploration \& Production, General Survey, National Iranian Oil Company.

[11] Berberian, M. (1995) Master "Blind” Thrust Faults Hidden under the Zagros Folds: Active Basement Tectonics and Surface Morphotectonic. Tectonophysics, 241, 193-224. http://dx.doi.org/10.1016/0040-1951(94)00185-C

[12] Hatzfeld, D., Tatar, M., Priestley, K. and Ghafory-Ashtiany, M. (2003) Seismological Constraints on the Crustal Structure beneath the Zagros Mountain Belt (Iran). Geophysical Journal International, 155, 403-410. http://dx.doi.org/10.1046/j.1365-246X.2003.02045.x

[13] Arian, M. (2011) A Preface on Salt Diapirism of Iran. Asar Nafis Press, Qum, 309 p.

[14] Arian, M. and Noroozpour, H. (2015) The Biggest Salt-Tongue Canopy of Central Iran. Open Journal of Geology, 5, 55-60. http://dx.doi.org/10.4236/ojg.2015.52005

[15] Asadian, F., Pourkermani, M. and Arian, M. (2007) Tectonic Geomorphology of Salt Structures in the Garmsar-Lasjerd Area. Geographical Research, 39, 75-84.

[16] Pourkermani, M. and Arian, M. (1997) Salt Domes of Central Iran. Journal of Humanities University of Sistan and Balouchestan, 3, 29-41.

[17] Arian, M. (2012) Salt Diapirism and Tectonics. Second Edition, Asar Nafis Press, Qum, 319 p.

[18] Arian, M. and Noroozpour, H. (2015) Tectonic Geomorphology of Iran's Salt Structures. Open Journal of Geology, 5, 61-72. http://dx.doi.org/10.4236/ojg.2015.52006

[19] Asadian, F. and Arian, M. (2009) Identification of Diapiric Provinces of Central Iran through Geological and Geographical Analysis. International Journal of Agriculture Environment \& Biotechnology, 2, 3443-3451.

[20] Arian, M. (2012) Clustering of Diapiric Provinces in the Central Iran Basin. Carbonates and Evaporites, 27, 9-18. http://dx.doi.org/10.1007/s13146-011-0079-9

[21] Pourkermani, M. and Arian, M. (1998) Tectonic Geomorphology of Salt Domes in West of Zanjan Province, Iran. Iran Journal of Research Geography, 47, 44-53

[22] Arian, M. and Feizi, F. (2010) The Significance of Faulting on the Surficial Spreading of Evaporitic Deposits in the Varamin-Semnan Area. Journal of Earth and Resources, 3, 1-20.

[23] Arian, M. (2011) Middle East Tectonics. Asar Nafis Press, Qum, 236 p.

[24] Arian, M. and Aram, Z. (2014) Relative Tectonic Activity Classification in the Kermanshah Area, Western Iran. Solid Earth, 5, 1277-1291. http://dx.doi.org/10.5194/se-5-1277-2014

[25] Mashal, M., Kermani, M.P., Charchi, A., Almasian, M. and Arian, M. (2013) Pattern of Structural Geology Underground in Eastern of North Dezfol Embayment. Advances in Environmental Biology, 7, 260-268.

[26] Pazhoohan, M., Arian, M., Ghorashi, M. and Khosrotehrani, K. (2014) A Study of Drainage Pattern Responses to Active Tectonics in Tadvan Region, SW Iran. Geodynamics, 1, 36-41.

[27] Rahimi, N. and Arian, M. (2014) Tectonic Geomorphplogy of Hamedan-Sosangerd Region, West Iran. Advances in Environmental Biology, 8, 119-124.

[28] Arian, M. and Hashemi, A. (2008) Seismotectonic Zoning in the Zagros. Journal of Sciences, 18, 63-76.

[29] Arian, M., Qorashi, M., Pourkermani, M. and Ahmadnia, A. (2003) Fractal Analysis of Mengharak Transcurrent Fault System in Zagros, in Iran. Proceedings of the Fourth International Conference on Seismology and Earthquake Engineering, Tehran, 4-6 May 2003.

[30] Baharvand, S., Pourkermani, M., Ajalloian, R., Arian, M. and Nouryazdan, A.R. (2010) Seymareh Landslide and Its Role in Environmental and Geomorphologic Changes of the Pole-Dokhtar Area. Journal of the Earth, 4, 13-24.

[31] Abdideh, M., Qorashi, M., Rangzan, K. and Arian, M. (2011) Assessment of Relative Active Tectonics Using Morphometric Analysis, Case Study of Dez River (Southwestern, Iran). Geosciences Scientific Quarterly Journal, 20, 3346. 
[32] Khodabakhshnezhad, A., Arian, M. and Pourkermani, M. (2008) The Elements of Fold Style Analysis in the Asmari Anticline (Zagros). Journal of Sciences, 18, 129-138.

[33] Arian, M., Pourkermani, M., Khodabakhshnezhad, A. and Noroozpour, H. (2011) Investigation of Oil Trap in the Asmari Anticline (Zagros, Iran). Indian Journal of Science and Technology, 4, 1696-1699.

[34] Khodabakhshnezhad, A., Arian, M. and Pourkermani, M. (2015) Folding Mechanism in the Asmari Anticline, Zagros, Iran. Open Journal of Geology, 5, 197-208.

[35] Arian, M. and Mohammadian, R. (2011) Analysis of Fractures in the Asmari Reservoir of Marun Oil Field (Zagros). Geosciences, 20, 87-96.

[36] Keynezhad, A., Pourkermani, M., Arian, M. and Saeedi, A. (2011) Dynamic Analysis of Fractures in North of TorudMoalleman Area (Central Iran, East South of Damghan). Geosciences, 20, 3-16.

[37] Arian, M., Maleki, Z. and Noroozpour, H. (2011) Cenozoic Diastrophism and Deformational Events in the East Central Alborz. Journal of Basic and Applied Scientific Research, 1, 2394-2400.

[38] Feizi, F., Arian, A. and Rahmani, R. (2007) Seismotectonic Zoning in the Eastern Part of the Central Alborz. Journal of Sciences, 17, 151-164.

[39] Khavari, R., Arian, M. and Ghorashi, M. (2009) Neotectonics of the South Central Alborz Drainage Basin, in NW Tehran, N Iran. Journal of Applied Sciences, 9, 4115-4126. http://dx.doi.org/10.3923/jas.2009.4115.4126

[40] Arian, M. and Bagha, N. (2012) Active Tectonics of Tehran Area, Iran. Journal of Basic and Applied Scientific Research, 2, 3805-3819.

[41] Bagha, N., Arian, M., Ghorashi, M., Pourkermani, M., El Hamdouni, R. and Solgi, A. (2014) Evaluation of Relative Tectonic Activity in the Tehran Basin, Central Alborz, Northern Iran. Geomorphology, 213, 66-87. http://dx.doi.org/10.1016/j.geomorph.2013.12.041

[42] Arian, M. and Feizi, F. (2005) Application of Geomorphic Indices to the Assessment of Relative Tectonic Activity Levels in the Alborz-Central Iran Border Zone (From the East of Varamin to the East of Semnan). Journal of Sciences, 15, 378-403.

[43] Arian, M., Bagha, N., Khavari, R. and Noroozpour, H. (2012) Seismic Sources and Neo-Tectonics of Tehran Area (North Iran). Indian Journal of Science and Technology, 5, 2379-2383.

[44] Moghimi, H., Arian, M. and Sorbi, A. (2015) Fault Movement Potential of Marzanabad Area, North Alborz, Iran. Open Journal of Geology, 5, 126-135. http://dx.doi.org/10.4236/ojg.2015.53012

[45] Arian, M. and Pourkermani, M. (2004) Tectonic Elements of South Flank in the East-Central Alborz Mountain. Journal of Sciences, 4, 359-368.

[46] Arian, M. and Qorashi, M. (2006) The Movement Potential Evaluation of the Major Quaternary Faults in Alborz-Central Iran Border Zone, from the East of Tehran to the East of Semnan. Journal of Geosciences, Geological Survey of Iran, 15, 184-188.

[47] Poroohan, N., Pourkermani, M. and Arian, M. (2013) An Assessment of Relationship in F-Parameter and Paleostress Fields in Heterogeneous Lithologies: Roudbar Area (Northwest of Iran). Australian Journal of Basic \& Applied Sciences, 7, 933-942.

[48] Poroohan, N., Poukermani, M. and Aryan, M. (2009) An Assessment on Correlations of Seismotectonic Parameters Preceding and Following Roudbar-Manjil Earthquake (Gilan, North of Iran). Australian Journal of Basic \& Applied Sciences, 3, 2643-2652.

[49] Farrokhnia, A.R., Pirasteh, S., Pourkermani, M. and Arian, M. (2011) Geo-Information Technology for Mass Wasting Hazard Zonation: Central-West Alborz-Iran. Disaster Advances, 4, 24-33.

[50] Khavari, R., Ghorashi, M. and Arian, M. (2009) Assessment of Relative Active Tectonics, South Central Alborz (North Iran). EGU General Assembly Conference Abstracts, 11, 1137.

[51] Sorbi, A., Arian, M. and Pourkermani, M. (2009) The Movement Potential Evaluation of the Major Quaternary Faults in Tehran Quadrangle. Journal of the Earth, 19, 176-182.

[52] Feizi, F. and Arian, M. (2006) The Classification of Thrust Fronts in the Alborz-Central Iran Border Zone from the East of Varamin to the East of Semnan. Journal of Sciences, 16, 75-87.

[53] Bazarchi, S., Jafari, M.R. and Arian, M. (2012) Geochemical Studies and Introduction of Anomaly Zones in Kandelus Sheet (Southwest of Baladeh). Journal of the Earth, 6, 67-75.

[54] Arian, M. and Pourkermani, M. (2004) Structural Significance of North Semnan and Attary Faults in Alborz-Central Iran Border Zone. Journal of Sciences, 14, 4551-4569.

[55] Arian, M. and Pourkermani, M. (2005) Cenozoic Diastrophism and Deformational Events in the Southern Flank of Central-East Alborz. Journal of Faculty Earth Sciences, 10, 43-51. 
[56] Arian, M., Pourkermani, M., Qorashi, M. and Ghasemi, M.R. (2003) North Semnan Fault System and Its Role on Basin Division. Proceedings of the 8th symposium of Geological Society of Iran, 2, 11-17.

[57] Pourkermani, M. and Arian, M. (2001) Structural Geomorphology of Northeastern Kurdistan, Sistan and Baluchestan University. Journal of Humanities, 7, 37-48.

[58] Mardani, Z., Ghorashi, M. and Arian, M. (2011) Geomorphic Signatures of Active Tectonics in the Talaghan Rud, Shah Rud and Sefidrud Drainage Basins in Central Alborz, N Iran. Geosciences, 20, 159-166.

[59] Sorbi, A., Arian, M. and Pourkermani, M. (2011) The Application of Geomorphic Indices to the Assessment of Relative Tectonic Activity Levels in Tehran Quadrangle. Journal of the Earth, 6, 1-9.

[60] Khavari, R., Ghorashi, M., Arian, M. and Khosrotehrani, K. (2010) Geomorphic Signatures of Active Tectonics in the Karaj Drainage Basin in South Central Alborz, N Iran. Geosciences, 19, 67-74.

[61] Javadi Mousavi, E. and Arian, M. (2015) Tectonic Geomorphology of Atrak River, NE Iran. Open Journal of Geology, 5, 106-114.

[62] Nouri, R., Jafari, M.R., Arian, M., Feizi, F. and Afzal, P. (2013) Correlation between Cu Mineralization and Major Faults Using Multifractal Modelling in the Tarom Area (NW Iran). Geologica Carpathica, 64, 409-416. http://dx.doi.org/10.2478/geoca-2013-0028

[63] Nouri, R., Jafari, M.R., Arian, M., Feizi, F. and Afzal, P. (2013) Prospection for Copper Mineralization with Contribution of Remote Sensing, Geochemical and Mineralographical Data in Abhar 1:100,000 Sheet, NW Iran. Archives of Mining Sciences, 58, 1071-1084. http://dx.doi.org/10.2478/amsc-2013-0074

[64] Nouri, R., Afzal, P., Arian, M., Jafari, M. and Feizi, F. (2013) Reconnaissance of Copper and Gold Mineralization Using Analytical Hierarchy Process (AHP) in the Rudbar 1: 100,000 Map Sheet, Northwest Iran. Journal of Mining and Metallurgy A: Mining, 49, 9-19.

[65] Arian, M. and Nouri, R. (2015) Lineament Tectonics and Mineralizatin in Tarom Area, North Iran. Open Journal of Geology, 5, 115-124. http://dx.doi.org/10.4236/ojg.2015.53011

[66] Feizi, F. and Arian, M. (2011) The Role of Structural Controllers in Geneses of Copper Deposits in 1:50000 Map of Saiin Qaleh. Journal of Sciences, 21, 1-10.

[67] Arian, M., Toudeshki, V.H. and Noroozpour, H. (2011) Active Tectonics of Qezel Ozan River Basin, NW Iran. Journal of Applied Environmental and Biological Sciences, 1, 291-295.

[68] Housini Toudeshki, V., Pourkermani, M., Arian, M. and Khosrotehrani, K.H. (2011) Influence of Structures on the Ghezel Ozan River. Geosciences, 21, 55-60.

[69] Housini Toudeshki, V. and Arian, M. (2011) Morphotectonic Analysis in the Ghezel Ozan River Basin, NW Iran. Journal of Geography and Geology, 3, 258-260. http://dx.doi.org/10.5539/jgg.v3n1p258

[70] Eshghi, Z., Arian, M. and Pourkermani, M. (2012) Structural Investigation on the Lak Mining Area (Bueen Zahra) Based on Remote Sensing, Used for Its Mineralization. Journal of the Earth, 6, 145-155.

[71] Arian, M., Pourkermani, M., Sistanipour, A. and Noroozpour, H. (2011) Kinematic Significance of Fold- and Fault-Related Fracture Systems in the Rafsanjan's Northeast Highlands (Central Iran). Journal of Basic and Applied Scientific Research, 1, 3398-3406.

[72] Arian, M., Pourkermani, M., Sistanipour, A. and Noroozpour, H. (2011) Seismicity and Fault Segmentation of BafqBaghin Fault System (Central Iran). Journal of Applied Environmental and Biological Sciences, 1, 382-396.

[73] Javadi Mosavi, E., Arian, M., Ghorashi, M. and Nazemi, M. (2012) Measurments of Geomorphic Indices in Tabas Area. Journal of the Earth, 7, 213-225.

[74] Arian, M. (2010) Earthquake-Fault Hazard Investigations in the Kerman Quadrangle. Journal of Sciences, 19, $176-182$.

[75] Javadi Mosavi, E. and Arian, M. (2015) Active Tectonics of Tabas Area, Central Iran. Open Journal of Geology, 5, 209-223.

[76] Jamalian Daryani, N., Arian, M. and Rashidnezhad Omran, N. (2015) Economic Tectonics of Copper in the Ardestan-Kahang Area, Central Iran by Remote Sensing. Open Journal of Geology, 5, 188-196. http://dx.doi.org/10.4236/ojg.2015.54017

[77] Morris, P. (1977) Basement Structures as Suggested by Aeromagnetic Surveys in South West Iran. Proceedings of the Second Iranian Petroleum Institute Earth Science Symposium, Tehran, 7-9 September 1977, 36 p.

[78] Arian, M., Ahmadnia, A., Qorashi, M. and Pourkermani, M. (2002) Structural Analysis of Mengharak Transcurrent Fault System in Zagros, Iran. Special GEO 2002 Conference Issue Geoarabia, 7, 209-210.

[79] Turcotte, D.L. (1997) Fractals and Chaos in Geology and Geophysics. Second Edition, Cambridge University Press, Cambridge, 398 p. http://dx.doi.org/10.1017/CBO9781139174695 